\title{
Peranan Guru PAI dalam Pendidikan Akhlak di Sekolah
}

\author{
Edi Kuswanto \\ Sekolah Lanjutan Tingkat Pertama (SLTP) 2 Dempet Demak \\ Email: edi2@gmail.com
}

\begin{abstract}
Abstrak
Pendidikan moral saat ini memiliki peran penting di suatu negara, sehingga layaknya pendidikan sekarang ini lebih diarahkan untuk membentuk karakter bangsa. Masalah yang timbul di bidang pendidikan, khususnya pendidikan moral merupakan tanggung jawab seorang pendidik (guru). Guru (pendidik) sebagai pelaksana kurikulum harus mampu menerapkan kurikulum dalam proses pembelajaran. Permasalahan yang diamati dalam penelitian ini adalah apa yang harus dilakukan guru (pendidik) supaya pendidikan akhlak tidak hanya dipahami oleh peserta didik tetapi mampu diaplikasikan dalam kehidupan sehari-hari. Penelitian ini merupakan penelitian kualitatif dengan pendekatan deskriptif menggunakan metode interaktif dan non interaktif. Dalam pendidikan moral di sekolah, guru memiliki peran yang sangat dominan, sedangkan peran yang dapat dilakukan oleh guru adalah sebagai berikut: 1) peran sebelum proses pembelajaran adalah: guru sebagai desainer instruksional, guru sebagai penjaga system nilai (teladan) serta guru pengganti orang tua; 2) peran dalam proses pembelajaran adalah: organizer, fasilitator, motivator, inovator dan mentor; 3) peran setelah proses pembelajaran adalah: evaluator.

Moral education has an important role in the state, so that education is directed to shape the character of the nation. Issues that arise in the educational field, especially moral education is the responsibility of educator (teacher). Teachers as curriculum implementers should be able to apply the curriculum in the learning process. The problems observed
\end{abstract}


in this study is what should teacher / educator do so that moral education is not only understood by learners but can be applied in everyday life. This research is a qualitative descriptive approach using interactive and non-interactive methods. In moral education at schools, teachers have a very dominant role, while the role which can be done by the teacher in outline as follows: 1) the role of pre-learning such as: teachers as instructional designers, teachers as a guard value (role model) as well as a substitute teacher parents; 2) role in the learning process such as: organizer, facilitator, motivator, innovator and mentor; 3) the role after learning such as: the evaluator.

Kata kunci: guru pendidikan agama islam, akhlak, moral

\section{Pendahuluan}

Pendidikan merupakan usaha sadar yang dilakukan oleh keluarga, masyarakat dan pemerintah, melalui kegiatan bimbingan, pengajaran, dan latihan, yang berlangsung di sekolah dan di luar sekolah sepanjang hayat, untuk mempersiapkan peserta didik agar dapat memainkan peranan dalam berbagai lingkungan hidup secara tepat di masa yang akan datang. Pendidikan adalah pengalaman-pengalaman belajar terprogram dalam bentuk pendidikan formal dan non formal, dan informal di sekolah, dan di luar sekolah, yang berlangsung seumur hidup yang bertujuan optimalisasi pertimbangan kemampuan-kemampuan individu, agar dikemudian hari dapat memainkan peranan hidup secara tepat. Dalam Undang-Undang (UU) Nomor 20 tahun 2003 tentang Sistem Pendidikan Nasional, pendidikan adalah usaha sadar dan terencana untuk mewujudkan suasana belajar dan proses pembelajaran agar peserta didik secara aktif mengembangkan potensi dirinya sehingga memiliki kekuatan spiritual keagamaan, pengendalian diri, kepribadian, kecerdasan, akhlak 
mulia, serta keterampilan yang diperlukan oleh dirinya, masyarakat, bangsa dan Negara.

Kebutuhan akan pendidikan merupakan hal yang tidak bisa dipungkiri, bahkan semua itu merupakan hak semua warga Negara, Berkenaan dengan ini, di dalam Undang-Undang Dasar (UUD) 1945 Pasal 31 ayat (1) secara tegas disebutkan bahwa; "Tiap-tiap warga Negara berhak mendapat pengajaran". Tujuan pendidikan nasional dinyatakan dalam Undang-Undang (UU) RI Nomor 20 Tahun 2003 Pasal 3 bertujuan untuk berkembangnya potensi peserta didik agar menjadi manusia yang beriman dan bertaqwa kepada Tuhan Yang Maha Esa, berakhlak mulia, sehat, berilmu, cakap, kreatif mandiri, dan menjadi warga Negara yang demokratis serta bertanggung jawab.

Sedangkan fungsi pendidikan menurut Undang-Undang (UU) Nomor 20 tahun 2003 adalah mengembangkan kemampuan dan membentuk watak serta peradaban bangsa yang bermartabat dalam rangka mencerdaskan kehidupan bangsa bertujuan untuk berkembangnya potensi peserta didik agar menjadi manusia yang beriman dan bertaqwa kepada Tuhan Yang Maha Esa, berahlak mulia, sehat, berilmu, cakap, kreatif, mandiri, dan menjadi warga negara yang demokratis serta bertanggung jawab. Selajalan dengan hal tersebut dalam Peraturan Pemerintah (PP) Nomor 17 Tahun 2010 tentang Pengelolaan Penyelenggaraan Pendidikan pada Pasal 17 Ayat (3) menyebutkan bahwa pendidikan dasar, termasuk Sekolah Menengah Pertama (SMP) bertujuan membangun landasan bagi berkembangnya potensi peserta didik agar menjadi manusia yang (a) beriman dan bertakwa kepada Tuhan Yang 
Maha Esa; (b) berakhlak mulia, dan berkepribadian luhur; (b) berilmu, cakap, kritis, kreatif, dan inovatif; (c) sehat, mandiri, dan percaya diri; (d) toleran, peka sosial, demokratis, dan bertanggungjawab.

Pendidikan agama sebagai bagian dari sistem pendidikan nasional memiliki tanggung jawab yang sama terhadap pencapaian dari tujuan pendidikan nasional. Pendidikan agama merupakan bagian pendidikan yang sangat penting yang berkenaan dengan aspek-aspek sikap dan nilai, antara lain akhlak, keagamaan dan sosial masyarakat. Agama memberikan motivasi hidup dalam kehidupan. Oleh karena itu agama perlu diketahui, dipahami, diyakini dan diamalkan oleh manusia Indonesia agar dapat menjadi dasar kepribadian sehingga dapat menjadi manusia yang utuh. Agama mengatur hubungan manusia dengan Allah SWT, manusia dengan manusia, hubungan manusia dengan alam dan hubungan manusia dengan dirinya yang dapat menjamin keselarasan, keseimbangan dan keserasian dalam hidup manusia, baik sebagai pribadi maupun sebagai anggota masyarakat dalam mencapai kebahagiaan lahiriah dan rohaniah.

Untuk mencapai fungsi dan tujuan pendidikan tersebut di atas peran pendidikan agama sangat diperlukan, tanpa kemudian menafikan peran dari pendidikan lainnya. Salah satu ruang lingkup pendidikan agama adalah pendidikan akhlak. Pendidikan akhlak di Sekolah merupakan sub bagian/materi dari mata pelajaran Pendidikan Agama Islam, walaupun begitu dengan adanya Kurikulum 2013, urgensi pendidikan akhlak di Sekolah memiliki peran yang sangat dominan sehingga dalam struktur Kurikulum 2013 Pendidikan Agama Islam 
dirubah menjadi Pendidikan Agama Islam dan Budi Pekerti. Hal ini disebabkan karena orientasi pendidikan yang dilakukan pada pengembangan kompetensi peserta didik bukan lagi berorientasi pada ketercapaian materi pelajaran. Dengan demikian apapun yang dilakukan oleh guru/pendidik dalam proses pembelajaran harus mampu mengoptimalkan potensi yang dimiliki peserta didik.

Berdasar pada argumentasi tersebut, persoalan krusial yang muncul adalah apa yang harus dilakukan guru/pendidik supaya pendidikan akhlak tidak hanya dipahami oleh peserta didik tetapi mampu diaplikasikan dalam kehidupan sehari-hari.

\section{Metode Penelitian}

Penelitian ini merupakan penelitian kualitatif dengan pendekatan deskriptif. Penelitian ini menggunakan metode interaktif dan metode non interaktif. Metode interaktif meliputi observasi berperan dan wawancara, sedangkan metode non interaktif meliputi observasi dan analisis dalam dokumen. Teknik analisis data dalam penelitian ini deskriptif-eksploratifanalisis.

\section{Pembahasan}

\section{Pendidikan Akhlak}

Akhlak secara terminologi berarti tingkah laku seseorang yang didorong oleh suatu keinginan secara sadar untuk melakukan suatu perbuatan yang baik. Akhlak merupakan bentuk jamak dari kata khuluk, berasal dari bahasa Arab yang berarti perangai, tingkah laku, atau tabiat. 
Cara membedakan akhlak, moral dan etika yaitu Dalam etika, untuk menentukan nilai perbuatan manusia baik atau buruk menggunakan tolok ukur akal pikiran atau rasio, sedangkan dalam moral dan susila menggunakan tolok ukur norma-norma yang tumbuh dan berkembang dan berlangsung dalam masyarakat (adat istiadat), dan dalam akhlaq menggunakan ukuran al-Qur'an dan al-Hadis untuk menentukan baikburuknya.

Menurut Rahmat Djatnika, bahwa pengertian akhlak dapat dibedakan menjadi dua macam, di antaranya menurut etimologi kata akhlak berasal dari bahasa Arab (ا خلا ق) bentuk jamak dari mufrodnya khuluq (خلق), yang berarti budi pekerti. Sinonimnya adalah etika dan moral. Etika berasal dari bahasa Latin, etos yang berarti kebiasaan. Moral berasal dari bahasa Latin juga, mores yang juga berarti kebiasaan. Sedangkan menurut terminolog, kata budi pekerti terdiri dari kata "budi" dan "pekerti". Budi adalah yang ada pada manusia, yang berhubungan dengan kesadaran, yang didorong oleh pemikiran, rasio yang disebut karakter. Pekerti adalah apa yang terlihat pada manusia, karena didorong oleh perasaan hati yang disebut dengan behaviour. Jadi, budi pekerti merupakan perpaduan dari hasil rasio dan rasa yang bermanifestasi pada karsa dan tingkah laku manusia (Djatnika, 1994:26).

Menurut Abuddin Nata, akhlak adalah perbuatan yang dilakukan dengan mendalam dan tanpa pemikiran, namun perbuatan itu telah mendarah daging dan melekat dalam jiwa, sehingga saat melakukan perbuatan tidak lagi memerlukan pertimbangan dan pemikiran (Nata, 1997: 5). 
Menurut Elizabeth B. Hurlock, behaviour which may be called "true morality" not only conforms to social standarts but also is carried out voluntarily, it comes with the transition from external to internal authority and consist of conduct regulated from within. Artinya, bahwa tingkah laku boleh dikatakan sebagai moralitas yang sebenarnya itu bukan hanya sesuai dengan standar masyarakat, tetapi juga dilaksanakan dengan suka rela, tingkah laku it terjadi melalui transisi dari kekuatan yang ada di luar (diri) dan ke dalam (diri) dan ada ketetapan hati dalam melakukan (bertindak) yang diatur dalam diri (Hurlock, 1978: 386).

Pendidikan akhlak adalah pendidikan mengenai dasar-dasar akhlak dan keutamaan perangai, tabiat yang harus dimiliki dan dijadikan kebiasaan oleh anak sejak masa analisa sampai ia menjadi seorang mukallaf, seseorang yang telah siap mengarungi lautan kehidupan. Ia tumbuh dan berkembang dengan berpijak pada landasan iman kepada Allah dan terdidik untuk selalu kuat, ingat bersandar, meminta pertolongan dan berserah diri kepada-Nya, maka ia akan memiliki potensi dan respon yang instingtif di dalam menerima setiap keutamaan dan kemuliaan. Di samping terbiasa melakukan akhlak mulia (Raharjo, 1999:63).

Pendidikan Akhlak dapat diartikan sebagai suatu kegiatan yang dilakukan secara sadar dan disengaja untuk memberikan bimbingan, baik jasmani maupun rohani, melalui penanaman nilai-nilai Islam, latihan moral, fisik serta menghasilkan perubahan ke arah positif, yang nantinya dapat diaktualisasikan dalam kehidupan, dengan kebiasaan bertingkah laku, berpikir dan berbudi pekerti yang luhur menuju terbentuknya 
manusia yang berakhlak mulia, di mana dapat menghasilkan perbuatan atau pengalaman dengan mudah tanpa harus direnungkan dan disengaja atau tanpa adanya pertimbangan dan pemikiran, yakni bukan karena adanya tekanan, paksaan dari orang lain atau bahkan pengaruh-pengaruh yang indah dan pebuatan itu harus konstan (stabil) dilakukan berulang kali dalam bentuk yang sering sehingga dapat menjadi kebiasaan.

\section{Dasar-dasar Pendidikan Akhlak}

Dasar pendidikan akhlak adalah al-Qur'an dan al-Hadis, karena akhlak merupakan sistem moral yang bertitik pada ajaran Islam. AlQur'an dan al-Hadis sebagai pedoman hidup umat Islam menjelaskan kriteria baik dan buruknya suatu perbuatan. Al-Qur'an sebagai dasar akhlak menjelaskan tentang kebaikan Rasulullah SAW sebagai teladan bagi seluruh umat manusia. maka selaku umat Islam sebagai penganut Rasulullah SAW sebagai teladan bagi seluruh umat manusia, sebagaimana firman Allah SWT dalam (Qs. al-Ahzab : 21) "Sesungguhnya telah ada pada (diri) Rasulullah itu suri tauladan yang baik bagimu (yaitu) bagi orang yang mengharap (rahmat) Allah dan (kedatangan) hari kiamat dan dia banyak menyebut Allah”.

Di dalam hadis juga disebutkan tentang betapa pentingnya akhlak di dalam kehidupan manusia. Bahkan diutusnya rasul adalah dalam rangka menyempurnakan akhlak yang baik, sebagaimana sabda Rasulullah SAW: Dari Abdullah menceritakan Abi Said bin Mansur berkata : menceritakan Abdul Aziz bin Muhammad dari Muhammad bin 'Ijlan dari Qo'qo' bin Hakim dari Abi Shalih dari Abi Hurairoh berkata 
Rasulullah SAW bersabda : Sesungguhnya Aku hanya diutus untuk menyempurnakan akhlak yang mulia (H.R.Ahmad).

Berdasarkan hadis tersebut di atas memberikan pengertian tentang pentingnya pendidikan akhlak dalam kehidupan manusia, di mana dengan pendidikan akhlak yang diberikan dan disampaikan kepada manusia tentunya akan menghasilkan orang-orang yang bermoral, lakilaki maupun perempuan, memiliki jiwa yang bersih, kemauan yang keras, cita-cita yang benar dan akhlak yang tinggi, mengetahui arti kewajiban dan pelaksanaannya, menghormati hak-hak manusia, mengetahui perbedaan buruk dan baik, memilih satu fadhilah karena cinta pada fadhilah, menghindari suatu perbuatan yang tercela dan mengingat Tuhan dalam setiap pekerjaan yang mereka lakukan.

\section{Tujuan Pendidikan Akhlak}

Tujuan pokok dari pendidikan Islam adalah mendidik budi pekerti dan pembentukan jiwa. Pendidikan yang diberikan kepada anak didik haruslah mengandung pelajaran-pelajaran akhlak. Setiap pendidik haruslah memikirkan akhlak dan memikirkan akhlak keagamaan sebelum yang lain-lainnya karena akhlak keagamaan adalah akhlak yang tertinggi, sedangkan akhlak yang mulia itu adalah tiang dari pendidikan Islam.

Dalam tujuan pendidikan akhlak dapat dibedakan menjadi dua macam, yaitu: 1) Tujuan Utama: Menurut Barnawy Umari, bahwa tujuan pendidikan akhlak secara umum meliputi: a) supaya dapat terbiasa melakukan yang baik, indah, mulia, terpuji serta menghindari yang buruk, jelek, hina dan tercela. b) supaya perhubungan kita dengan Allah 
SWT dan dengan sesama makhluk selalu terpelihara dengan baik dan harmonis (Umari, 1984: 2). Menurut Ali Hasan bahwa tujuan pokok akhlak adalah agar setiap orang berbudi (berakhlak), bertingkah laku (tabiat) berperangai atau beradat istiadat yang baik atau yang sesuai dengan ajaran Islam (Hasan, 1988: 11). 2) Tujuan Khusus: a) menumbuhkan pembentukan kebiasaan berakhlak mulia da beradat kebiasaan yang baik. b) Memantapkan rasa keagamaan pada siswa, membiasakan diri berpegang pada akhlak mulia dan membenci akhlak yang rendah. c) Membiasakan siswa bersikap rela, optimis, percaya diri, emosi, tahan menderita dan sabar. d) Membimbing siswa ke arah dikap yang sehat dan dapat membantu mereka berinteraksi sosial yang baik, mencintai kebaikan untuk orang lain, suka menolong, sayang kepada yang lemah, dan menghargai orang lain. e) Membiasakan siswa bersopan santun dalam berbicara dan bergaul baik di sekolah maupun di luar sekolah. f) Selalu tekun beribaah dan mendekatkan diri kepada Allah dan bermuamalah yang baik (Thoha, 1999: 136).

Adapun menurut Muhammad 'Athiyyah Al-Abrasyi menjelaskan tujuan dari pendidikan moral dan akhlak dalam Islam adalah membentuk orang-orang yang bermoral baik, keras kemauan, sopan dalam bicara dan mulia dalam bertingkah laku dan perangai, bersifat bijaksana, sempurna, sopan dan beradab, ikhlas, jujur dan suci. Jiwa dari pendidikan Islam adalah pendidikan moral dan akhlak (Al-Abrasyi, 2003: 114).

Dijelaskan juga menurut Ahmad Amin, bahwasannya tujuan pendidikan akhlak (etika) bukan hanya mengetahui pandangan atau teori, bahkan setengah dari tujuan itu adalah mempengaruhi dan mendorong 
kehendak kita supaya membentuk hidup suci dan menghasilkan kebaikan dan kesempurnaan dan memberi faedah kepada sesama manusia. maka etika itu adalah mendorong kehendak agar berbuat baik, akan tetapi ia tidak selalu berhasil kalau tidak ditaati oleh kesucian manusia (Amin, 1975: 6-7).

\section{Pendidikan Akhlak di Sekolah}

Merespons sejumlah kelemahan dalam pelaksanaan pendidikan akhlak dan budi pekerti yang telah terjadi di lapangan, maka perlu dilakukan upaya inovasi pendidikan karakter. Inovasi tersebut adalah: (1) Pendidikan karakter dilakukan secara terintegrasi ke dalam semua mata pelajaran. Integrasi yang dimaksud meliputi pemuatan nilai-nilai ke dalam substansi pada semua mata pelajaran dan pelaksanaan kegiatan pembelajaran yang memfasilitasi dipraktik-kannya nilai-nilai dalam setiap aktivitas pembelajaran di dalam dan di luar kelas untuk semua mata pelajaran.(2) Pendidikan karakter juga diintegrasikan ke dalam pelaksanaan kegiatan pembinaan peserta didik. (3) Selain itu, pendidikan karakter dilaksanakan melalui kegiatan pengelolaan semua urusan di sekolah yang melibatkan semua warga sekolah.

Pelaksanaan pendidikan karakter secara terpadu di dalam semua mata pelajaran merupakan hal yang baru bagi sebagian besar sekolah, baik di tingkat SD, SMP, maupun SMA. Terlebih saat ini ujicoba baru dilaksanakan di tingkat SMP pada beberapa Provinsi, diantaranya D.I. Yogyakarta, Makassar, Pekan Baru, Jakarta, dan Surabaya. Oleh karena itu, dalam rangka membina pelaksanaan pendidikan karakter secara 
terpadu di dalam seluruh mata pelajaran, perlu disusun panduan pelaksanaan pendidikan karakter yang terintegrasi ke dalam pembelajaran.

Sebenarnya selama ini tanpa disadari semua guru SD khususnya telah menanamkan nilai-nilai yang baik dalam pembentukan karakter peserta didiknya. Namun hal itu hanya sebagai sisipan yang tidak termuat dalam silabus maupun RPP. Oleh karena itu perlu adanya optimalisasi pendidikan karakter dalam pembelajaran, agar gaung pena-naman karakter melalui pembelajaran dapat benar-benar dirasakan peserta didik.

Pada era globalisasi saat ini memang bangsa kita telah mampu menghasilkan Sumber Daya Manusia (SDM) yang secara kuantitas sudah memadai, namun dari segi kualitas masih sangat perlu ditingkatkan agar dihasilkan SDM yang mampu berkompetisi dengan negara berkembang, bahkan negara maju. Selain SDM yang demikian, masih ada satu hal penting yang harus ditekankan, yaitu menghasilkan SDM yang beretika, bermoral, sopan santun, dan mampu berinteraksi dengan masyarakat secara baik, dengan tetap memegang teguh kepribadian bangsa. Dengan kata lain, bangsa kita menginginkan terbentuknya generasi penerus bangsa yang berkarakter dan berkualitas akhlaknya sekaligus cerdas intelektualnya. Banyak contoh anak didik yang cerdas, tetapi kualitas akhlaknya kurang baik, maka mereka tidak dapat diharapkan untuk menjadi generasi penerus yang dapat membangun bangsa kita.

Berdasarkan penelitian di Harvard University Amerika menunjukkan kesuksesan seseorang tidak ditentukan semata-mata oleh pengetahuan dan kemampuan teknis (hard skill), tetapi lebih oleh 
kemampuan mengelola diri dan orang lain (soft skill). Penelitian ini mengungkapkan, kesuksesan hanya ditentukan sekitar 20\% oleh hard skill dan sisanya $80 \%$ oleh soft skill. Bahkan orang-orang tersukses di dunia dapat berhasil dikarenakan lebih banyak didukung kemampuan soft skill daripada hard skill. Hal ini mengisyaratkan bahwa mutu pendidikan karakter peserta didik sangat penting untuk ditingkatkan, karena otak yang hebat tanpa disertai kepribadian yang baik, maka akan sulit diterima di masyarakat nasional maupun internasional.

Karakter merupakan nilai-nilai perilaku manusia yang berhubungan dengan Tuhan Yang Maha Esa, diri sendiri, sesama manusia, lingkungan, dan kebangsaan yang terwujud dalam pikiran, sikap, perasaan, perkataan, dan perbuatan berdasarkan norma-norma agama, hukum, tata krama, budaya, dan adat istiadat.

Pendidikan karakter adalah suatu sistem penanaman nilai-nilai karakter kepada warga sekolah yang meliputi komponen pengetahuan, kesadaran atau kemauan, dan tindakan untuk melaksanakan nilai-nilai tersebut, baik terhadap Tuhan Yang Maha Esa (YME), diri sendiri, sesama, lingkungan, maupun kebangsaan sehingga menjadi manusia yang beerkualiatas akhlaknya. Dalam pendidikan karakter di sekolah, semua komponen (stakeholders) harus dilibatkan, termasuk komponenkomponen pendidikan itu sendiri, yaitu isi kurikulum, proses pembelajaran dan penilaian, kualitas hubungan, penanganan atau pengelolaan mata pelajaran, pengelolaan sekolah, pelaksanaan aktivitas atau kegiatan ko-kurikuler, pemberdayaan sarana prasarana, pembiayaan, dan etos kerja seluruh warga dan lingkungan sekolah. 
Terlepas dari berbagai kekurangan dalam praktik pendidikan di Indonesia, apabila dilihat dari Standar Nasional Pendidikan yang menjadi acuan pengembangan kurikulum KTSP, dan implementasi pembelajaran dan penilaian di sekolah, tujuan pendidikan di tingkat SD, SMP, dan SMA sebenarnya dapat dicapai dengan baik. Pembinaan karakter juga termasuk dalam materi yang harus diajarkan dan dikuasai serta direalisasikan oleh peserta didik dalam kehidupan sehari-hari. Permasalahannya, pendidikan karakter di sekolah selama ini baru menyentuh pada tingkatan pengenalan norma atau nilai-nilai, dan belum pada tingkatan internalisasi dan tindakan nyata dalam kehidupan seharihari.

Sebagai upaya untuk meningkatkan kesesuaian dan mutu pendidikan karakter, Kementerian Pendidikan Nasional mengembangkan grand design pendidikan karakter untuk setiap jalur, jenjang, dan jenis satuan pendidikan. Grand design menjadi rujukan konseptual dan operasional pengembangan, pelaksanaan, dan penilaian pada setiap jalur dan jenjang pendidikan. Konfigurasi karakter dalam konteks totalitas proses psikologis dan sosial-kultural tersebut dikelompokan dalam: Olah Hati (Spiritual and emotional development), Olah Pikir (intellectual development), Olah Raga dan Kinestetik (Physical and kinestetic development), dan Olah Rasa dan Karsa (Affective and Creativity development). Pengembangan dan implementasi pendidikan karakter perlu dilakukan dengan mengacu pada grand design tersebut.

Menurut UU No 20 Tahun 2003 Tentang Sistem Pendidikan Nasional pada Pasal 13 Ayat 1 menyebutkan bahwa Jalur pendidikan 
terdiri atas pendidikan formal, nonformal, dan informal yang dapat saling melengkapi dan memperkaya. Pendidikan informal adalah jalur pendidikan keluarga dan lingkungan. Pendidikan informal sesungguhnya memiliki peran dan kontribusi yang sangat besar dalam keberhasilan pendidikan. Peserta didik mengikuti pendidikan di sekolah hanya sekitar 7 jam per hari, atau kurang dari 30\%. Selebihnya (70\%), peserta didik berada dalam keluarga dan lingkungan sekitarnya. Jika dilihat dari aspek kuantitas waktu, pendidikan di sekolah berkontribusi hanya sebesar 30\% terhadap hasil pendidikan peserta didik.

Selama ini, pendidikan informal terutama dalam lingkungan keluarga belum memberikan kontribusi berarti dalam mendukung pencapaian kompetensi dan pembentukan karakter peserta didik. Hal ini disebabkan oleh berbagai hal, diantaranya kesibukan dan aktivitas kerja orang tua yang relatif tinggi, kurangnya pemahaman orang tua dalam mendidik anak di lingkungan keluarga, pengaruh pergaulan di lingkungan sekitar, dan pengaruh media elektronik. Salah satu alternatif untuk mengatasi permasa-lahan tersebut adalah melalui pendidikan karakter terpadu, yaitu memadukan dan mengoptimalkan kegiatan pendidikan informal lingkungan keluarga dengan pendidikan formal di sekolah. Dalam hal ini, waktu belajar peserta didik di sekolah perlu dioptimal-kan agar peningkatan mutu hasil belajar, terutama pembentukan karakter peserta didik sesuai tujuan pendidikan dapat dicapai.

Pendidikan karakter dapat diintegrasikan dalam pembelajaran pada setiap mata pelajaran. Materi pembelajaran yang berkaitan dengan 
norma atau nilai-nilai pada setiap mata pelajaran perlu dikembangkan, dieksplisitkan, dikaitkan dengan konteks kehidupan sehari-hari. Dengan demikian, pembelajaran nilai-nilai karakter tidak hanya pada tataran kognitif, tetapi menyentuh pada internalisasi, dan pengamalan nyata dalam kehidupan peserta didik sehari-hari di masyarakat.

Kegiatan ekstra kurikuler yang selama ini diselenggarakan sekolah merupakan salah satu media yang potensial untuk pembinaan karakter dan peningkatan mutu akademik peserta didik. Kegiatan ekstra kurikuler merupakan kegiatan pendidikan di luar mata pelajaran untuk membantu pengembangan peserta didik sesuai dengan kebutuhan, potensi, bakat, dan minat mereka melalui kegiatan yang secara khusus diselenggarakan oleh pendidik dan atau tenaga kependidikan yang berkemampuan dan berkewenangan di sekolah. Melalui kegiatan ekstra kurikuler diharapkan dapat mengembangkan kemam-puan dan rasa tanggung jawab sosial, serta potensi dan prestasi peserta didik.

Pendidikan karakter di sekolah juga sangat terkait dengan manajemen atau pengelolaan sekolah. Pengelolaan yang dimaksud adalah bagaimana pendidikan karakter direncanakan, dilaksanakan, dan dikendalikan dalam kegiatan-kegiatan pendidikan di sekolah secara memadai. Pengelolaan tersebut meliputi nilai-nilai yang perlu ditanamkan, muatan kurikulum, pembelajaran, penilaian, pendidik dan tenaga kependidikan, dan komponen terkait lainnya. Dengan demikian, manajemen sekolah merupakan salah satu media yang efektif dalam pendidikan karakter di sekolah. 
Pendidikan karakter seharusnya membawa peserta didik ke pengenalan nilai secara kognitif, penghayatan nilai secara afektif, dan akhirnya ke pengamalan nilai secara nyata. Permasalahan pendidikan karakter yang selama ini ada di sekolah perlu segera dikaji, dan dicari alternatif-alternatif solusinya, serta perlu dikembangkannya secara lebih operasional sehingga mudah diimplementasikan di sekolah.

Arti pendidikan karakter secara terintegrasi di dalam proses pembelajaran adalah pengenalan nilai-nilai, fasilitasi diperolehnya kesadaran akan pentingnya nilai-nilai, dan penginternalisasian nilai-nilai ke dalam tingkah laku peserta didik sehari-hari melalui proses pembelajaran, baik yang berlangsung di dalam maupun di luar kelas pada semua mata pelajaran. Dengan demikian, kegiatan pembelajaran, selain untuk menjadikan peserta didik menguasai kompetensi (materi) yang ditargetkan, juga dirancang dan dila-kukan untuk menjadikan peserta didik mengenal, menyadari/peduli, dan menginter-nalisasi nilai-nilai dan menjadikannya perilaku.

\section{Kondisi Nyata Pendidikan Akhlak di Sekolah}

Perubahan kurikulum pendidikan dari kurikulum 1994 menjadi kurikulum KBK (tahun 2004) dan disempurnakan tahun 2006 yang kemudian dikenal dengan Kurikukulum Tingkat Satuan Pendidikan (KTSP), diubah lagi dengan kurikulum 2013 yang sejak bulan Juli 2014 diberlakukan serentak diseluruh Indonesia, yaitu untuk kelas VII dan VIII pada tingkat SMP. Pendidikan Agama Islam dan Budi Pekerti adalah pendidikan yang berlandaskan pada aqidah yang berisi tentang 
keesaan Allah Swt sebagai sumber utama nilai-nilai kehidupan bagi manusia dan alam semesta. Sumber lainnya adalah akhlak yang merupakan manifestasi dari aqidah, yang sekaligus merupakan landasan pengembangan nilai-nilai karakter bangsa Indonesia. Dengan demikian, Pendidikan Agama Islam dan Budi Pekerti adalah pendidikan yang ditujukan untuk dapat menserasikan, menselaraskan dan menyeimbangkan antara iman, Islam, dan ihsan.

Pada prinsipnya perubahan kurikulum tersebut tidak serta merta merubah mainset para pendidik/guru tidak terkecuali guru Pendidikan Agama Islam (PAI) di sekolah. Perubahan paradigma pembelajaran dari teacher centered beralih kepada student centered, pada kenyataannya hanya sebatas wacana, tulisan pada kurikulum serta materi pada diklatdiklat peningkatan mutu pendidik saja dan pelaksanaannya masih jauh dari harapan. Guru/pendidik masih menjadi sumber dan subjek yang dominan dari pembelajaran sehingga peserta didik kurang diberi peran yang besar dalam proses pembelajaran. Guru menjadi sentral pembelajaran, tanpa guru di ruang kelas proses pembelajaran tidak dapat terlaksana. Begitu dominannya guru, sehingga terdapat anggapan bahwa guru adalah kurikulum. Tanpa guru itu sama artinya tanpa kurikulum sehingga pada akhirnya proses pembelajaran tidak dapat terlaksana.

Penggunaan media baik media sederhana maupun media berbasis teknologi komputer serta penggunaan model pembelajaran yang mendukung terhadap pembelajaran saintifik sebagaimana amanah dari kurikulum 2013 pada kenyataannya masih banyak guru yang belum melaksanakan. Guru masih menggunakan pembelajaran konfensional 
dengan metode ceramah serta kurang memanfaatkan sumber dan media secara maksimal.

Perubahan dari KTSP (kurikulum 2006) menjadi Kurikulum 2013, memberi keleluasaan guru dalam melaksanakan pembelajaran. segala kebutuhan guru yang menunjang proses pembelajaran sudah disiapkan oleh pemerintah, mulai dari silabus, buku ajar bagi siswa dan buku guru sampai pada pedoman mata pelajaran (PMP) sebagai acuan bagi guru dalam proses pembelajaran sudah disediakan secara lengkap. Tugas guru hanya membuat perangkat pembelajaran yang hanya berupa Rencana Pelaksanaan Pembelajaran (RPP). Tetapi pada kenyataannya Rencana Pelaksanaan Pembelajaran yang menjadi tugas guru sebagian besar tidak dibuat sendiri (tanpa menafikan ada guru yang membuat sendiri), kecenderungan guru menggunakan Rencana Pelaksanaan Pembelajaran (RPP) yang dibuat oleh KKG/MGMP tanpa melakukan koreksi dan analisis yang didasarkan pada karakteristik dan kebutuhan peserta didik dan sekolah (hanya sebatas merubah nama instansi, nama guru dan kepala sekolah).

Secara umum di dalam proses pembelajaran agama termasuk didalamnya pembelajaran materi akhlak, guru PAI masih berorientasi pada ketercapaian materi pelajaran bukan pada kompetensi yang ingin dicapai. Sehingga evaluasi yang dilaksanakan oleh guru cenderung bersifat pengetahuan, sedangkan evaluasi pada aspek sikap dan keterampilan jarang dilakukan oleh guru. Padahal dalam kurikulum 2013 evaluasi yang dilakukan menggunakan penilaian outentik yang memotret semua aspek baik sikap, pengetahuan maupun ketrampilan. 


\section{Idealitas Pendidikan Akhlak di Sekolah}

Berdasar dari pengalaman - pengalaman pembelajaran pendidikan akhlak yang penulis dan beberapa guru lakukan sebagaimana uraian diatas,. Menurut hemat kami (penulis) setidaknya ada 3 (tiga) hal yang harus menjadi perhatian yang serius agar pembelajaran akhlak dapat berhasil dengan baik dalam artian tidak hanya sebatas pemahaman akan tetapi pesan pembelajaran dapat diaplikasikan dalam kehidupan seharihari.

\section{Desain Kurikulum Pendidikan Akhlak di Sekolah.}

Kurikulum pendidikan dewasa ini adalah pendidikan berbasis kompetensi. Kurikulum ini menitik beratkan pada pengembangan kemampuan untuk melakukan (kompetensi) tugas-tugas tertentu sesuai dengan standar performansi yang telah ditetapkan. (Majid, 2008: 24). Rumusan ini menunjukkan bahwa kegiatan pembelajaran diarahkan untuk memberdayakan semua potensi yang dimiliki peserta didik untuk menguasai kompetensi yang diinginkan. kegiatan pembelajaran mengembangkan kemampuan untuk mengetahui, memahami, melakukan sesuatu, hidup dalam kebersamaan dan mengaktualisasikan diri.

Menurut Puskur Litbang Diknas (2004) dalam Abdul Majid (2008 : 24) menjelaskan bahwa dalam kegiatan pembelajaran perlu : 1) berpusat pada peserta didik; 2) mengembangkan kreatifitas peserta didik; 3) menciptakan kondisi yang menyenangkan dan menantang; 4) bermuatan nilai, etika, estetika, logika dan kinestika; 5) menyediakan pengalaman belajar yang beragam. 
Dari pemahaman pengertian diatas dapat diambil benang merah bahwa dalam menyusun kurikulum materi akhlak dalam hal ini adalah penyusunan Rencana Pelaksanaan Pembelajaran (RPP) guru harus memperhatikan kondisi lingkungan tempat guru mengajar, baik kondisi sekolah, masyarakat sekitar dan juga kondisi psikologis peserta didik. Akan tetapi perhatian tersebut tetap mengacu pada standar yang telah ditetapkan oleh pemerintah.

\section{Konsep Pembentukan Akhlak di sekolah.}

Pendidikan agama Islam adalah merupakan bagian terpenting yang berkenaan dengan aspek sikap dan nilai-nilai antara lain akhlak, karena pendidikan agama memberikan motivasi hidup dan kehidupan, dan juga merupakan alat pengembangan dan pengendalian diri untuk terciptanya manusia sebagaimana diharapkan. Peranan guru dalam proses pembinaan sangat berperan untuk mencapai tujuan pembelajaran di sekolah. Tujuan pembelajaran pendidikan agama Islam diantaranya adalah menjadi manusia yang berakhlak mulia, sesuai dengan tutunan dan ajaran agama. Mengingat setiap guru memiliki kepribadian, kemampuan profesional, dedikasi dan tanggungjawab yang semuanya merupakan esensi dalam proses pendidikan. Esensi sebuah lembaga pendidikan adalah kualitas pembinaan yang diciptakan oleh guru yang profesional. Dalam konteks inilah peranan pendidikan agama Islam dalam pembentukan akhlak siswa dikaji secara ilmiah.

Secara konseptual proses pembentukan akhlak merupakan bagian tak terpisahkan dari kurikulum. Oleh karena itu, kurikulum yang baik 
harus terdapat dalam proses pembinaan. Atas dasar itu proses pendidikan agama Islam mencakup perencanaan, pelaksanaan dan penilaian dan metode bimbingan guru Pendidikan Agama Islam dalam membina akhlak siswa menjadi manusia yang berakhlak mulia. Secara lebih luas, proses pembentukan akhlak siswa ditentukan oleh variabel yang lebih luas seperti peranan orang tua di rumah, lingkungan sosial, lingkungan pergaulan, media, dan secara internal kurikulum pendidikan itu sendiri.

\section{Peran Guru Pendidikan Akhlak di sekolah.}

Pendidik adalah orang yang dengan sengaja mempengaruhi orang lain untuk mencapai tingkat kemanusian yang lebih tinggi. (Suwarno, 2009: 37) Ini artinya bahwa setiap pendidik/guru bertanggungjawab terhadap perkembangan peserta didiknya. Pendidik/guru pada dasarnya memiliki peran yang sangat fital dalam proses pembelajaran, baik tidaknya kualitas pembelajaran salah satunya dipengaruhi oleh kualitas pendidiknya. Pendidik yang memiliki kualitas tinggi dapat menciptakan dan mendesain materi pembelajaran yang lebih dinamis dan konstruktif. Mereka juga akan mampu mengatasi kelemahan materi dan subyek didiknya dengan menciptakan suasana miliu yang kondusif dan strategi mengajar yang efektif dan dinamis. (Roqib, 2009: 43)

Untuk menjaga kualitas pendidik/guru, pemerintah membuat rambu-rambu dengan diterbitkannya UU No. 14 tahun 2005 tentang guru dan dosen, Permendiknas No. 16 tahun 2007 tentang kualifikasi akademik dan kompetensi guru serta peraturan-peraturan lainnya. Pada dasarnya tugas pendidik adalah mendidik dengan mengupayakan 
pengembangan seluruh potensi peserta didik, baik aspek kognitif, afektif maupun psikomotorik. Potensi peserta didik ini harus berkembang secara seimbang dan terintegrasi dalam diri peserta didik. Dalam melaksanakan tugas pembelajaran sebagai pendidik harus; 1) menguasai materi pelajaran, 2) menggunakan metode pembelajaran agar peserta didik mudah menerima dan memahami pelajaran, 3) melakukan evaluasi pendidikan yang dilakukan, 4) menindaklanjuti hasil evaluasinya. (Roqib, 2009: 50-51)

Selain tugas-tugas di atas, pendidik Pendidikan Agama Islam (khususnya materi akhlak) harus mampu berkomunikasi yang efektif dengan peserta didik. Dengan komunikasi yang efektif proses pembelajaran lebih bermakna dan efisien. Menurut Abin Syamsuddin (2003) dalam Akhmad Sudrajat (2008: 1) mengemukakan bahwa dalam pengertian pendidikan secara luas, seorang guru yang ideal seyogyanya dapat berperan sebagai: (1) Konservator (pemelihara) sistem nilai yang merupakan sumber norma kedewasaan; (2) Inovator (pengembang) sistem nilai ilmu pengetahuan; (3) Transmitor (penerus) sistem-sistem nilai tersebut kepada peserta didik; (4) Transformator (penterjemah) sistem-sistem nilai tersebut melalui penjelmaan dalam pribadinya dan perilakunya, dalam proses interaksi dengan sasaran didik; (5) Organisator (penyelenggara) terciptanya proses edukatif yang dapat dipertanggungjawabkan, baik secara formal (kepada pihak yang mengangkat dan menugaskannya) maupun secara moral (kepada sasaran didik, serta Tuhan yang menciptakannya). 
Abin Syamsuddin menambahkan dengan mengutip pemikiran Gagde dan Berliner, mengemukakan peran guru dalam proses pembelajaran peserta didik, yang mencakup: (1) Guru sebagai perencana (planner) yang harus mempersiapkan apa yang akan dilakukan di dalam proses belajar mengajar (pre-teaching problems). (2) Guru sebagai pelaksana (organizer), yang harus dapat menciptakan situasi, memimpin, merangsang, menggerakkan, dan mengarahkan kegiatan belajar mengajar sesuai dengan rencana, di mana ia bertindak sebagai orang sumber (resource person), konsultan kepemimpinan yang bijaksana dalam arti demokratik \& humanistik (manusiawi) selama proses berlangsung (during teaching problems). (3) Guru sebagai penilai (evaluator) yang harus mengumpulkan, menganalisa, menafsirkan dan akhirnya harus memberikan pertimbangan (judgement), atas tingkat keberhasilan proses pembelajaran, berdasarkan kriteria yang ditetapkan, baik mengenai aspek keefektifan prosesnya maupun kualifikasi produknya.

Selanjutnya, dalam konteks proses belajar mengajar di Indonesia, Abin Syamsuddin menambahkan satu peran lagi yaitu sebagai pembimbing (teacher counsel), di mana guru dituntut untuk mampu mengidentifikasi peserta didik yang diduga mengalami kesulitan dalam belajar, melakukan diagnosa, prognosa, dan kalau masih dalam batas kewenangannya, harus membantu pemecahannya (remedial teaching).

\section{Kesimpulan}

Berangkat dari kondisi nyata, kondisi ideal, serta tujuan pendidikan akhlak di sekolah sebagaimana telah dijelaskan diatas, maka 
dapat dianalisa bahwa peran peserta guru dalam pendidikan akhlak di sekolah sebagai berikut: sebelum proses pembelajaran: guru pendidikan akhlak di sekolah memiliki peran sebagai berikut: (a) Guru sebagai perencana/planer/desainer, artinya sebelum proses pembelajaran guru harus merencanakan sendiri proses belajar mengajar yang akan dilakukan baik berupa perencanaan kurikulum, alat/media yang akan digunakan, bahkan instrumen apa yang akan digunakan dalam melakukan evaluasi pembelajaran. (b) Guru sebagai konservator/penjaga sistem nilai, dengan kata lain guru bisa sebagai tauladan/contoh yang baik bagi muridnya. (c) Guru sebagai pengganti orang tua ketika di sekolah, dengan peran ini guru bisa dekat dengan murid sehingga bisa membantu kesulitankesulitan yang dihadapi oleh muridnya. Pada waktu proses pembelajaran: guru pendidikan akhlak di sekolah memiliki peran sebagai berikut: (a) Guru sebagai organisator, maksudnya adalah guru harus dapat menciptakan situasi, memimpin, merangsang, menggerakkan, dan mengarahkan kegiatan belajar mengajar sesuai dengan rencana. (b) Guru sebagai fasilitator, artinya guru mampu memfasilitasi siswa dalam rangka mengembangkan potensi dirinya. (c) Guru sebagai teman belajar. (d) Guru sebagai pembimbing (teacher counsel), di mana guru dituntut untuk mampu mengidentifikasi peserta didik yang diduga mengalami kesulitan dalam belajar, melakukan diagnosa, prognosa, dan kalau masih dalam batas kewenangannya, harus membantu pemecahannya (remedial teaching). (e) Guru sebagai transformator (penterjemah) sistem-sistem nilai tersebut melalui penjelmaan dalam pribadinya dan perilakunya, dalam proses interaksi dengan sasaran didik; (f) Guru sebagai inovator, 
artinya guru memberikan inovasi-inovasi dalam proses pembelajaran maupun pengembangan sistem nilai dalam hal ini akhlak. Sesudah proses pembelajaran: guru pendidikan akhlak di sekolah memiliki peran sebagai penilai (evaluator) yang harus mengumpulkan, menganalisa, menafsirkan dan akhirnya harus memberikan pertimbangan (judgement), atas tingkat keberhasilan proses pembelajaran, berdasarkan kriteria yang ditetapkan, baik mengenai aspek keefektifan prosesnya maupun kualifikasi produknya.

\section{Daftar Pustaka}

Al-Abrasyi, Muhammad 'Athiyyah. 2003. Prinsip-Prinsip Dasar Pendidikan. Bandung : Pustaka Setia

Amin, Ahmad. 1975. Etika (Ilmu Akhlak). Jakarta : Bulan Bintang

Djatnika, Rahmat. 1994. Sistem Ethika Islami (Akhlak Mulia). Jakarta: Balai Pustaka.

Hasan, M. Ali. 1988. Tuntunan Akhlak. Jakarta : Bulan Bintang.

Hurlock, Elizabeth B. 1978. Child Development. Kugllehisa, Mc. Grow Hill

Majid, Abdul. 2008. Perencanaan pembelajaran; mengembangkan standar kompetensi guru. Bandung: PT Remaja Rosdakarya.

Nata, Abuddin. 1997. Akhlak Tasawuf. Jakarta : PT. Raja Grafindo Persada.

Peraturan Pemerintah Nomor 17 tahun 2010 tentang Pengelolaan Penyelenggaraan Pendidikan.

Permendikbud No. 58 tahun 2014 tentang Kurikulum SMP

Permendiknas Nomor 16 tahun 2007 tentang Kualifikasi Akademik dan Kompetensi Guru

Raharjo, dkk., 1999. Pemikiran Pendidikan Islam, Kajian Tokoh Klasik dan Kontemporer. Yogyakarta: Pustaka Pelajar.

Roqib, Moh. 2009. Ilmu pendidikan Islam; pengembangan pendidikan integrative di sekolah, keluarga dan masyarakat. Jogjakarta: PT LKiS. 
Sudrajat, Akhmad. 2008. Peran guru dalam proses pendidikan. http://akhmadsudrajat.wordpress.com/2008/03/06/peran-gurudalam-proses-pendidikan. diakses 31/3/2011 jam 12.59

Suwarno, Wiji. 2009. Dasa-dasar ilmu pendidikan. Cet. III. Jogjakarta: Ar-ruzz Media Grup.

Thoha, Chabib. Saifudin Zuhri, dkk., 1999. Metodologi Pengajaran Agama. Yogyakarta: Pustaka Pelajar.

Umari, Barnawy. 1984. Materi Akhlak. Solo: Ramadhani

Kemendikmas, 2005, Undang-Undang Nomor 14. Kementerian

Undang-Undang Nomor 20 tahun 2003 tentang Sistem Pendidikan Nasional.

Undang-Undang Dasar 1945 dan Amandemen. 